\title{
Effect of physical exercises and perceived stress interaction on students' satisfaction with life
}

\author{
Olefir V.O. ${ }^{1 \mathrm{ABCDE}}$, Kuznetsov M.A. ${ }^{2 \mathrm{ABDE}}$, Plokhikh V.V. ${ }^{3 \mathrm{ABDE}}$ \\ ${ }^{1}$ Department of General Psychology, V.N. Karazin Kharkiv National University, Ukraine \\ ${ }^{2}$ Department of Practical Psychology, H.S. Skovoroda Kharkiv National Pedagogical University, Ukraine \\ ${ }^{3}$ Department of Psychology of Development and Social Communications, K.D. Ushynsky South Ukrainian National \\ Pedagogical University, Ukraine
}

Authors' Contribution: A - Study design; B - Data collection; C - Statistical analysis; D - Manuscript Preparation; E - Funds Collection.

$\begin{array}{ll}\begin{array}{l}\text { Abstract } \\ \text { Purpose: }\end{array} & \begin{array}{l}\text { to find out the effect of regular physical exercises and perceived stress interaction on students' satisfaction } \\ \text { with life. }\end{array} \\ \text { Material: } & \begin{array}{l}\text { The study involved university students }\left(\mathrm{n}=355 ; M_{\text {age }}=19,97 ; \mathrm{SD}=2,12\right) \text {. The moderator analysis was } \\ \text { conducted according to the cross-sectional questionnaire. }\end{array} \\ \text { Results: } & \begin{array}{l}\text { It is determined that the difference in students' satisfaction with life at the average and high perceived stress } \\ \text { is due to physical exercises. The influence of the interaction of variables (physical activity x perceived stress) } \\ \text { on satisfaction with life was statistically significant. }\end{array} \\ \text { Conclusions: } & \begin{array}{l}\text { It is revealed the peculiarities of interaction between the physical exercises and perceived stress. The reduce } \\ \text { of satisfaction with life under the influence of perceived stress is more typical for those students who do not } \\ \text { regularly practice physical exercises. Physical exercises act as a buffer against stress. } \\ \text { physical exercises, perceived stress, satisfaction with life, students. }\end{array} \\ \text { Keywords: } & \end{array}$

\section{Introduction}

Satisfaction with life is a key indicator of subjective well-being [1], along with the predominance of positive affection over negative. It is defined as a cognitive process in which people value their satisfaction with life. The evaluation is based on a comparison of their life situation with their own set of standards [2]. It is a reflexive evaluation of how much everything has been and remains well. Satisfaction with life can be understood as a product of differences between achievements and aspirations. Satisfaction with life is related to the physical and mental health of a person. It can determine the level of human happiness lifetime [3].

The study of satisfaction predictors with life and the mechanisms for its support is always of considerable interest. Researches among students are especially relevant. Student's age is a period of active professional and personal self-determination. One of the criteria for the success of self-determination can be a high level of satisfaction with life.

Students are confronted with a number of difficulties in life. These are worries about success, perfectionist standards, uncertainty about their future, economic difficulties, family problems, and difficulties in dealing with the opposite sex. The period of study at the university predetermines the use of time and financial resources by students without the guarantee of a satisfactory return.

Such circumstances of life can be perceived by students as threatening. Therefore, they will cause stress (according to the transactional model of stress) [4]. University students are at a socio-demographic age, in which stress disorders are more prevalent $[5,6,7]$. The prevalence of depression, anxiety, and stress among (c) Olefir V.O., Kuznetsov M.A., Plokhikh V.V., 2019

doi:10.15561/18189172.2019.0105 students from France, Romania and the Republic of Moldova was respectively $39.0 \%, 47.0 \%, 35.8 \%$ [8]. The high level of perceived stress stipulates the emergence of negative emotions: anxiety, depression. The analysis of publications over 20 years has shown that the average prevalence of depression among students is $31 \%$. It is much higher than in the general population [9]. Many of these disorders have high temporal stability. They can lead to long-term psycho-physiological changes. They increase the risk of cardiovascular disease. In some studies, there is a steady negative correlation between stress and quality of life in university students. It is expressed in the deterioration of their physical and mental health [10-12]. This fact is confirmed in another study [13].

These facts generated interest in methods applied to alleviate stress; to ways to maintain a good quality of life. One of the important ways to overcome stress among students is physical activity. There is plenty of evidence that regular physical exercise has a direct positive effect on health and satisfaction with life $[14,15,16]$. The study of Maher et al. [17] determines the connection between physical activity and sedentary lifestyle with life satisfaction in college students (from 18 to 25 years old). The authors found that an increase in daily physical activity and a reduction in the daily sedentary lifestyle could improve the satisfaction of college students' lives. M. Gerber, S. Brand, S. Herrmann, and others used objective data concerning physical activity. It is proved that active physical exercises are an important factor in stress management, pain perception and sleep quality [18]. However, the usual levels of physical activity were not associated with satisfaction with life in young people [19].

The direct effect of physical exercises on the general 
satisfaction of life in a number of secondary analyzes is placed in question (for example, [20]). It is emphasized that personal characteristics and environmental features can mediate or mitigate this correlation.

The connection between stress and active exercise is also ambiguous. There are studies which didn't support this conclusion [21]. The majority of studies confirmed that stress is negatively associated with physical activity [22].

It is necessary to define the term "physical exercise" and distinguish it from the terms associated with it: physical activity; sport. Physical activity refers to the widest category that covers all types of human movements. Sport is an organized competitive physical activity. It is focused on the victories and performances at an elite level. Physical exercises are aimed at recovery and rest. These are structured and scheduled physical loads [23]. We define the term "physical exercises" as a sub-group of physical activity, which are planned and purposeful attempts to improve health and well-being.

Previous studies demonstrate a significant impact of perceived stress and physical exercise on student satisfaction with life. However, there are no studies devoted to the impact of these factors on the satisfaction of life in interaction. It is known that the study of the interaction effect allows to answer the question: "how?" or "under what conditions?" the predictive variable affects the dependent variable.

The hypothesis of research is the follows: the regular exercise is a buffer between perceived stress and student satisfaction.

The purpose of the study is to find out the interaction effect of regular physical exercises and perceived stress on student satisfaction with life.

\section{Material and methods}

Participants. The sample consisted of 355 university students (men - $\mathrm{n}=154$, women - $\mathrm{n}=201$, age 17-26, average age - 19.97 years, $\mathrm{SD}=2.12$ ) (Kharkiv and Odessa, Ukraine). Participants were selected using a random sample. Before the study, all students were informed about the content of the questionnaire. Students were informed that participation is voluntary and confidential.

\section{Design of the research:}

Psychological and socio-demographic indicators were obtained using questionnaires. Students' questionnaire surveys were conducted in groups up to 20 persons. The survey lasted approximately twenty minutes. All scales meet requirements standards of psychometric quality.

It was applied Ukrainian translation of the scale of satisfaction with life for evaluation satisfaction with life (SWLS; [24]). It consists of five points. Typical questions: "I'm satisfied with my life" or "The actual living conditions are the best." Students were asked to indicate their degree of agreement with five statements on the 7-point Likert scale (from 1 = "totally disagree" to 7 = "totally agree"). The higher is the amount of points, the more people consider themselves happy and satisfied with their lives. In this study, this scale was demonstrated by Alpha Cronbach 0.752 .

Stress was measured on a perceived stress scale (PSS; [25]). This is a 10-point instrument that measures the perception of stress. Participants were asked to choose how often they felt certain feelings and thoughts during the last month. It was used 5-point Likert scale in the range from 0 (never) to 4 (very often). Examples of questions: "How often have you been worried the last month because of unforeseen events?", "How often did you feel nervous tension or stress last month?"

The four points $(4,5,7,8)$ were reciprocal. Therefore, these points were inverted. The final score was obtained by summing all the marks by 10 points. Higher scores point to a higher level of perceived stress. Ukrainian translation of the PSS was applied in this study. The coefficient of internal consistency was 0.836 .

The regularity of physical exercises was evaluated with the help of the question: "Do you practice physical exercises for at least an hour and at least three times a week?". Consent was encoded as " 1 ", and disagreement - as " 0 ".

Statistical analysis: Descriptive statistics (average values, standard deviations) and correlations between variables are calculated. The moderator analysis was conducted on the basis of regression analysis. All calculations were made applying SPSS version 19.0. The analysis of the interaction effect was carried out applying the PROCESS macros ([26]).

\section{Results}

Descriptive statistics, correlations between regular exercise physical activity, level of perceived level of stress and satisfaction with life students are shown in Table 1.

Table 1. Descriptive statistics and correlations of the analyzed variables

\begin{tabular}{|c|c|c|c|c|c|}
\hline Variables & $M$ & $S D$ & $\mathbf{Y}$ & $\mathbf{x}$ & M \\
\hline $\begin{array}{l}\text { Satisfaction with life } \\
\text { (Y) }\end{array}$ & 16.32 & 5.27 & 1 & & \\
\hline Perceived stress $(\mathrm{X})$ & 18.23 & 6.16 & $-.565^{* * *}$ & 1 & \\
\hline Physical exercises (M) & .52 & .50 & $.296^{* * *}$ & -.087 & 1 \\
\hline
\end{tabular}

Note. ${ }^{* * *} \mathrm{p}<0.001$.

Perceived stress (Table 1) negatively correlates with satisfaction with life $(r=-0.565 ; \mathrm{p}<0.001)$. The regularity of exercises correlates positively with life satisfaction $(r$ $=0.296 ; \mathrm{p}<0.001)$. It wasn't detected the interrelation between perceived stress and physical exercises.

The results of regression analysis are presented in Table 2 in the general regression model of life satisfaction with centered perceived stress $(\mathrm{X}), \mathrm{Y}=-0.557 \mathrm{X}+2,628 \mathrm{M}$ $+0.215 \mathrm{XM}+15,080$. The regression model explains $39.5 \%$ of the dispersion of life satisfaction $\left(\mathrm{F}_{(3 ; 351)}=\right.$ 76.513; $\mathrm{p}<0.000)$. 
In a regression model $\mathrm{Y}=\mathrm{i}_{1}+\mathrm{b}_{1} \mathrm{X}+\mathrm{b}_{2} \mathrm{M}+\mathrm{b}_{3} \mathrm{XM} \mathrm{b}_{1}$ and $b_{2}$ are conditional effects [26]. These coefficients of regression estimate the effect of $\mathrm{X}$ when $\mathrm{M}=0$ and the influence of $M$ when $X=0$. respectively.

The coefficient of regression for the variable of physical exercises is $b_{1}=2,628$. It is statistically different from zero $(p<0.000)$. This is the predicted difference in the satisfaction with life between active students (regularly practice physical exercises) and passive students (having zero according to the scale of perceived stress, $M=0$ ). The coefficient is positive. It means that inactive students $(\mathrm{X}=1)$, satisfaction with life is higher.

The regression coefficient for the perceived stress scale is $b_{2}=-0.557$. It is also statistically significantly different from zero $(p=0.000)$. This is the predicted difference in the satisfaction with life between two passive students, which differ in one unit in their perception of stress $(X=$ $0)$. The sign is negative.

The regression coefficient for physical exercises and perceived stress is $b_{3}=0.215$. This coefficient quantifies how changes the effect of physical activity on the satisfaction with life changes with the perceived stress per standard unit. Here b3 statistically significantly differs from zero $(p=0.003)$. This means that the effect of physical activity on satisfaction with life depends on the interaction of perceived stress and physical exercises. An increase in perceived stress per unit leads to a difference in the satisfaction with life between passive and active students (by 0.215 units).

In fact, reducing the satisfaction with life under the influence of perceived stress is refracted through physical exercises. Active students are less inclined to reduce satisfaction with life under the influence of stressful circumstances of life. When one variable reduces the influence of another variable on the criterion, this variable buffers the influence of another variable. In our study, the role of a buffer variable plays the regularity of exercises.

Table 2 demonstrates the inclusion of the interaction increases $\mathrm{R}^{2}$ by 0.021 . Interaction is $2.0 \%$ of dispersion in satisfaction with life, without conditional effects $\left[\mathrm{F}_{\mathrm{var}}\right.$ $(1.351)=8.956, p=0.003]$. It may seem like a small value. However, it is the order that can usually be found in behavioral research. Fig. 1 shows that the effect of buffering is really strong.

\section{Discussion}

In the presented study, the relationship between regular exercise with physical activity perceived stress, and student satisfaction is considered. In previous studies, we studied basically separate links between stress and physical activity, or stress and satisfaction with life, or physical exercise and life satisfaction. We studied the relationship between these three constructs. We hypothesized that regular exercise would be a kind of buffer. He softens the relationship between perceived stress and student satisfaction. Our hypothesis was confirmed. It was found that the effect of the interaction of physical exercises and perceived stress on satisfaction with the life of students is statistically significant.

Other researchers have shown the relationship between physical exercise and stress indicators. In this study, there was no significant association between exercise and perceived stress. It coincides with some studies [21, 22]. Non-consistency of the results may be due to some factors and conditions of research. The research involved people of different ages. The physical exercises of different types and intensity were also applied.

In general, the positive effect of the interaction of physical exercises and stress can be explained both at the level of physiological and psychological factors. So, physical activity can significantly increase the production of serotonin and endorphins in the brain. It contributes to a sense of well-being. Physical exercises contribute to the new growth of neurons in the adult's brain, especially in the hippocampus [27]. As a result, it is reduced the feeling of anxiety and depression.

Psychological explanation of the positive effect of regular physical exercises meet the psychological needs of the person. It is about the need to increase selfefficacy, achievement of mastery, overcoming alienation, strengthening the autonomy and enhancing belonging. Satisfaction of such needs affects the satisfaction of various spheres of life, which contributes to the satisfaction with life in general [28]. Our previous studies

Table 2. Regression analysis of satisfaction with life $(\mathrm{Y})$ as a function of perceived stress $(\mathrm{X})$ and physical exercises (M), n-355

\begin{tabular}{|c|c|c|c|c|c|c|}
\hline \multicolumn{7}{|c|}{$\begin{array}{l}\text { Dependent variable: } \\
Y \text { - satisfaction with life }\end{array}$} \\
\hline \multirow[b]{2}{*}{ Predictors } & \multirow[b]{2}{*}{ Coefficient } & \multirow[b]{2}{*}{ SE } & \multirow[b]{2}{*}{$\mathbf{t}$} & \multirow[b]{2}{*}{$\mathbf{p}$} & \multicolumn{2}{|c|}{ 95\% confidence interva } \\
\hline & & & & & low & up \\
\hline Constant & 15.080 & .308 & 49.031 & .000 & 14.475 & 15.685 \\
\hline $\mathrm{x}$ & 2.628 & .438 & 5.996 & .000 & 1.766 & 3.490 \\
\hline M & -.557 & .047 & -11.791 & .000 & -.650 & -.464 \\
\hline $\mathrm{X} \times \mathrm{M}$ & .215 & .072 & 2.993 & .003 & .074 & .357 \\
\hline \multicolumn{7}{|c|}{ Increase $\mathrm{R}^{2}$ due to interaction } \\
\hline \multirow[t]{2}{*}{$\mathrm{X} \times \mathrm{M}$} & $\mathrm{R}^{2}$-var. & $F$ & $d f 1$ & $d f 2$ & $p$ & \\
\hline & .021 & 8.956 & 1 & 351 & .003 & \\
\hline
\end{tabular}


25

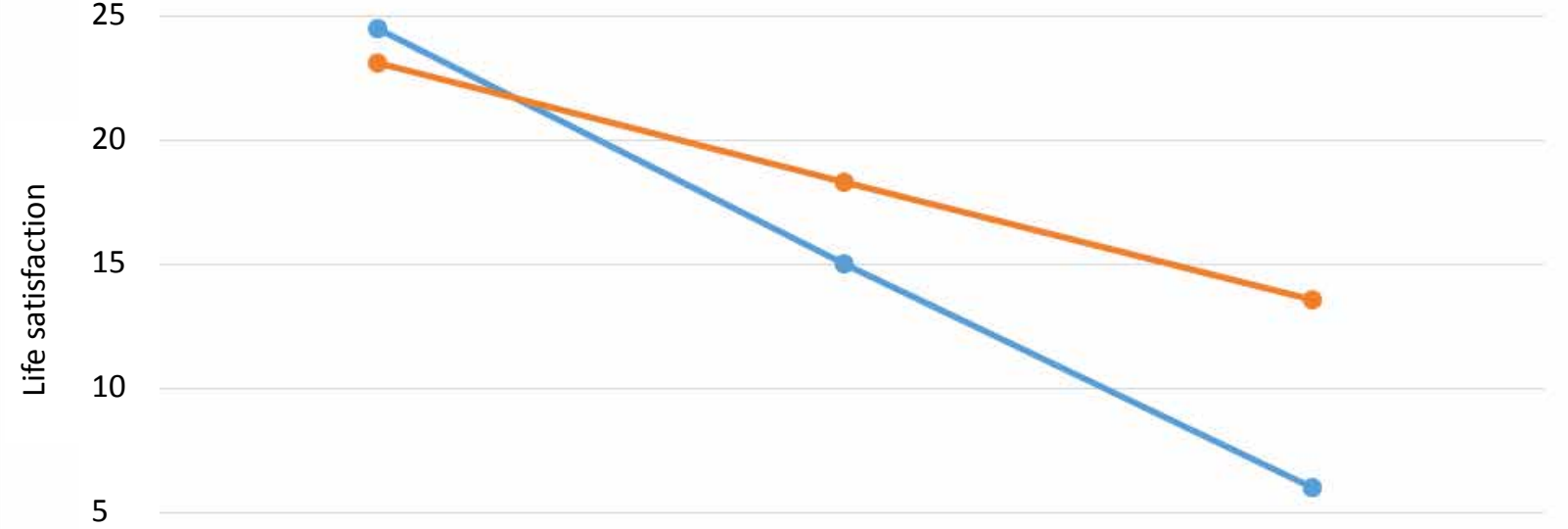

Low

Average

High

Perceived stress

- physical exercises No $\rightarrow$ physical exercises Yes

Fig. 1. Regression of satisfaction with life on physical exercises at three levels of perceived stress.

$[29,30]$ determined that people with a high index of personal resources (self-efficacy, self-control, viability, and optimism) are more capable to manage potential threats. They feel a lower level of excitement or anxiety, stress in the form of burnout. These personal resources are flexible and forming during life. Therefore physical exercises can be an effective means for their purposeful correction and formation. In addition, physical exercises can affect the quality of life. They provide opportunities to satisfy peak moments [31].

This study is expanding previous studies. This study evaluates the effect of physical activity and perceived stress with students' satisfaction with life.

The results of this study deserve attention. But there are certain limitations that can be leveled out in future studies. Firstly, the participants of this study were only young age students. Therefore, the result can not be generalized to the entire adult population.

Secondly, current results do not foresee causal relationships between perceived stress, physical exercises, and satisfaction with life (this study was cross-sectional). The prospect of further research is to carry out research on longitudinal plans. They could help to establish causal relationships between physical exercises, perceived stress, and life satisfaction.

\section{Conclusions}

Thus, the obtained results confirm the hypothesis that physical exercises act as a buffer against the stress. They contribute to satisfaction with life at university students. The revealed features of the interaction of physical exercises with perceived stress are expressed in the fact that reducing the satisfaction of life under the influence of perceived stress is more characteristic of passive students (practice physical exercises not regularly). It is required the development of targeted activities among the university students. Such actions should be directed at the promotion and organization of physical exercises. The urgent task is to conduct long-term studies. The basis of such studies is objective indicators of motor behavior. It will help to extend the information about their impact on the quality of life of students.

\section{Conflict of interest}

The author declares that there is no conflict of interests. 


\section{References}

1. Erdogan B, Bauer TN, Truxillo DM, Mansfield LR. Whistle While You Work: A Review of the Life Satisfaction Literature. Journal of Management, 2012; 38(4): 1038-1083. https://doi.org/10.1177/0149206311429379

2. Coffman D, Gilligan TD. Social Support, Stress, and Self-Efficacy: Effects on Students' Satisfaction. Journal of College Student Retention, 2002; 4(1): 53-66. https://doi.org/10.2190/BV7X-F87X-2MXL-2B3L

3. Diener E, Chan MY. Happy People Live Longer: Subjective Weil-Being Contributes to Health and Longevity. Applied Psychology: Health and Well-been, 2011; 3(1): 1-43. https://doi.org/10.1111/j.1758-0854.2010.01045.x

4. Lazarus RS, Folkman S. Stress, appraisal, and coping. N.Y.: Springer; 1984.

5. Chao RCL. Managing Perceived Stress among College Students: The Roles of Social Support and Dysfunctional Coping. Journal of College Counseling, 2012; 15: 5-21. https://doi.org/10.1002/j.2161-1882.2012.00002.x

6. Darling CA, McWey LM, Howard SN, Olmstead SB. College student stress: The influence of interpersonal relationships on sense of coherence. Stress and Health, 2007; 23: 215-549. https://doi.org/10.1002/smi.1139

7. Reddy KJ, Menon KR, Thattil A. Academic Stress and its Sources Among University Students. Biomedical and Pharmacology Journal, 2018; 11(1): 531-537. https://doi.org/10.13005/bpj/1404

8. Habihirwe P, Porovecchio S, Bramboiu I, Ciobanu E, Croituru C, Cazacu I, Peze T, Ladner J, Tavolacci M. Depression, anxiety and stress among college students in three European countries. European Journal of Public Health, 2018; 28(4). https://doi.org/10.1093/eurpub/cky214.026

9. Ibrahim AK, Kelly SJ, Adams CE, Glazebrook C. A systematic review ofstudiesofdepressionprevalenceinuniversitystudents. Journal of Psychiatric Research, 2013; 47(3): 391-400. https://doi.org/10.1016/j.jpsychires.2012.11.015

10.Civitci A. Perceived Stress and Life Satisfaction in College Students: Belonging and Extracurricular Participation as Moderators. Procedia - Social and Behavioral Sciences, 2015; 205: 271-281. https://doi.org/10.1016/j.sbspro.2015.09.077

11.Hui TX, Ramzan UBM. Relationship of Perceived Stress and Life Satisfaction among Medical Students: A Cross-sectional Study. British Journal of Medicine \& Medical Research, 2017; 20(10): 1-7. https://doi.org/10.9734/BJMMR/2017/31693

12.Lee J, Kim EY, Wachholtz A. The effect of perceived stress on life satisfaction: The mediating effect of selfefficacy. Chongsonyonhak Yongu, 2016; 23(10): 29-47. https://doi.org/10.21509/KJYS.2016.10.23.10.29

13. Ribeiro IJS, Pereira R, Freire IV, de Oliveira BG, Casotti CA, Boery EN. Stress and Quality of Life Among University Students: A Systematic Literature Review. Health Professions Education, 2017; 4(2): 70-77. https://doi.org/10.1016/j.hpe.2017.03.002

14.Kim J-H, McKenzie LA. The Impacts of Physical Exercise on Stress Coping and Well-Being in University Students in the Context of Leisure. Health, 2014; 6: 2570-2580. https://doi.org/10.4236/health.2014.619296

15.Sato M. Exercise and Weil-Being. In: Razon S, Sachs ML.Applied Exercise Psychology: The Challenging Journey from Motivation to Adherence. New York: Routledge; 2017.

16.Standage M, Gillison FB, Ntoumanis N, Treasure DC. Predicting students' physical activity and health-related wellbeing: A prospective cross-domain investigation of motivation across school physical education and exercise settings. Journal of Sport and Exercise Psychology, 2012; 34(1): 37-60. https://doi.org/10.1123/jsep.34.1.37

17.Maher JP, Doerksen SE, Elavsky S, Conroy DE. Daily satisfaction with life is regulated by both physical activity and sedentary behavior. Journal of Sport and Exercise Psychology, 2014; 36(2): 166-178. https://doi.org/10.1123/jsep.2013-0185

18.Gerber M, Brand S, Herrmann C, Colledge F, HolsboerTrachsler E, Pühse U. Increased objectively assessed vigorousintensity exercise is associated with reduced stress, increased mental health and good objective and subjective sleep in young adults. Physiology \& Behavior, 2014; 135: 17-24. https://doi.org/10.1016/j.physbeh.2014.05.047

19. Maher JP, Pincus AL, Ram N, Conroy DE. Daily Physical Activity and Life Satisfaction across Adulthood. Developmental Psychology, 2015; 51(10): 1407-1419. https://doi.org/10.1037/dev0000037

20.Lehnert K, Sudeck G, Conzelmann A. Subjective wellbeing and exercise in the second half of life: a critical review of theoretical approaches. European Review of Aging and Physical Activity, 2012; 9: 87-102. https://doi.org/10.1007/s11556-012-0095-3

21.Nguyen-Michel ST, Unger JB, Hamilton J, Spruijt-Metz D. Associations between physical activity and perceived stress/hassles in college students. Stress and Health, 2006; 22(3): 179-188. https://doi.org/10.1002/smi.1094

22.Stults-Kolehmainen MA, Sinha R. The Effects of Stress on Physical Activity and Exercise. Sports Medicine, 2014; 44(1): 81-121. https://doi.org/10.1007/s40279-013-0090-5

23.Berger BG, Tobar DA. Exercise and the quality of life. In: Morris T, Terry P. The new sport and exercise psychology companion. Morgantown, WV: Fitness Information Technology; 2011.

24.Diener E Emmons, RA, Larsen RJ, Griffin S. The Satisfaction With Life Scale. Journal of Personality Assessment, 1985; 49(1): 71-75. https://doi.org/10.1207/s15327752jpa4901_13

25.Cohen S, Kamarck T, Mermelstein R. A global measure of perceived stress. Journal of Health and Social Behavior, 1983; 24: 385-396. https://doi.org/10.2307/2136404

26. Hayes AF. Introduction to mediation, moderation, and conditional process analysis: A regression-based approach. New York, NY, US: Guilford Press; 2013.

27.Anderson E, Shivakumar G. Effects of exercise and physical activity on anxiety. Frontiers in Psychiatry, 2013, 4. https://doi.org/10.3389/fpsyt.2013.00027

28.Newman DB, Tay L, Diener E. Leisure and subjective wellbeing: A model of psychological mechanisms as mediating factors. Journal of Happiness Studies: An Interdisciplinary Forum on Subjective Well-Being, 2014; 15(3): 555-578. https://doi.org/10.1007/s10902-013-9435-x

29. OlefirV.Personality resources as a Mediator of the Relationship between Antecedents of Stress and Pre-competitive Anxiety. Journal of Physical Education and Sport, 18(6), 2230-2234. https://doi.org/10.7752/jpes.2018.04335

30. Olefir VA, Bosnjuk VF. Personality resources as Moderators in Relationship between Learning environment Demands and Student Burnout. Visnik V.N. Karazin Kharkiv National University. A Series of «Psychology», 2018;65: 21-29.

31.Csikszentmihalyi M. Finding flow: The psychology of engagement with everyday life. New York, NY, US: Basic Books; 1997. 


\section{Information about the authors:}

Olefir V.A.; (Corresponding author); http://orcid.org/0000-0003-4482-0150; general_psychology@karazin.ua; Department of General Psychology, V.N. Karazin Kharkiv National University; 4, Svobody Sq., Kharkiv, 61022, Ukraine.

Kuznetsov M.A.; http://orcid.org/0000-0002-2685-5475; kpp.khnpu@gmail.com; Department of Practical Psychology, H.S. Skovoroda Kharkiv National Pedagogical University; 29, Alchevskyh St., Kharkov, 61002, Ukraine.

Plokhikh V.V.; http://orcid.org/0000-0001-7897-3417; pdpu@pdpu.edu.ua; Department of Psychology of Development and Social Communications, K.D. Ushynsky South Ukrainian National Pedagogical University; 26, Staroportofrankivs`ka St., Odesa, 65020. Ukraine.

Cite this article as:

Olefir VO, Kuznetsov MA, Plokhikh VV. Effect of physical exercises and perceived stress interaction on students' satisfaction with life. Pedagogics, psychology, medical-biological problems of physical training and sports, 2019;23(1):30-35. https://doi.org/10.15561/18189172.2019.0105

The electronic version of this article is the complete one and can be found online at: https://www.sportpedagogy.org.ua/index.php/PPS/issue/archive

This is an Open Access article distributed under the terms of the Creative Commons Attribution License, which permits unrestricted use, distribution, and reproduction in any medium, provided the original work is properly cited (http://creativecommons.org/licenses/by/4.0/deed.en).

Received: 15.01.2019

Accepted: 15.02.2019; Published: 27.02.2019 